\title{
US farm-science head quits
}

\author{
Departure of director from National Institute of Food and Agriculture casts uncertainty \\ over future of flagship funding programme.
}

\section{BY HEIDI LEDFORD}

A nascent revolution in US agricultural science lost its leader last week. Roger Beachy, director of the National Institute of Food and Agriculture (NIFA) in Washington DC, resigned his post, effective on 20 May, saying that he wants to spend more time with his family in St Louis, Missouri. His departure from the agency, part of the US Department of Agriculture (USDA), after less than two years in the job has left researchers wondering what will become of Beachy's pet project: the controversial overhaul of NIFA's flagship competitive grants programme, the Agriculture and Food Research Initiative (AFRI).

"The future is very much uncertain," says Paul Bertsch, a soil scientist at the University of Kentucky in Lexington. "We're going to have this large vacuum created when Roger leaves."

Beachy, a prominent plant biologist who retains a position at Washington University in St Louis, has worked doggedly to raise the political profile of agricultural research and to dispel the field's reputation for being outdated. He radically changed the AFRI last year, designing interdisciplinary projects to tackle societal challenges - such as adapting to climate change and combating childhood obesity - and to deliver tangible results.

Overall, Beachy feels that the first year under the programme's new regime was a success; many researchers have told him that they appreciate the push towards interdisciplinary projects. And one of his goals to attract new talent to agricultural research - has already been met. In 2010, the AFRI received grant proposals from more than 300 institutions, extending the programme's reach well beyond the roughly 100 public universities that traditionally carry out most

\section{A GROWING CONCERN}

Budget increases in recent years for the US Agriculture and Food Research Initiative.

\begin{tabular}{|c|c|}
\hline 2008 & US\$190.8 million \\
\hline 2009 & $\$ 201.5 \mathrm{~m}$ \\
\hline 2010 & $\$ 262.5 \mathrm{~m}$ \\
\hline 2011 & $\$ 265 \mathrm{~m}$ \\
\hline 2012 & $\$ 325 \mathrm{~m}$ (requested) \\
\hline
\end{tabular}

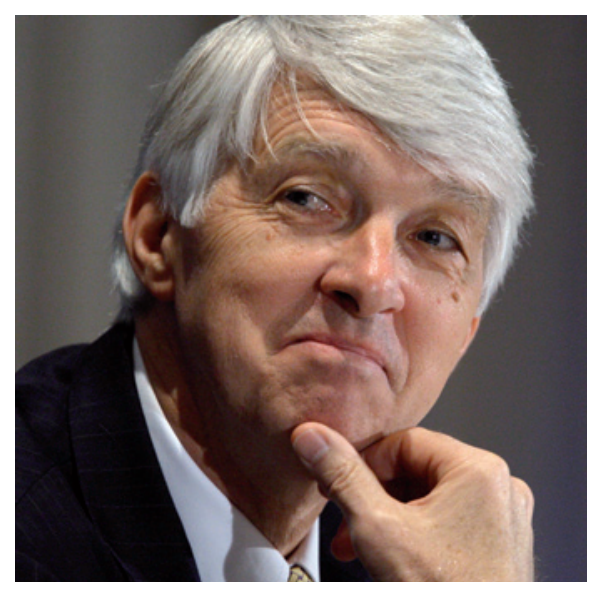

Roger Beachy promoted interdisciplinary science, but now wants to spend more time with his family.

government-funded agricultural research in the United States.

But the changes left many in the field reeling. The AFRI's latest projects were unusually specific - for example, the 2010 climate-change programme awarded grants to researchers studying cereal crops such as maize (corn) but not grasslands - leading to charges that the requirements were too restrictive and, in some cases, seemed to have been written with particular grant recipients in mind. Beachy denies this and says that the calls for proposals were specific to ensure results that would catch the eye of politicians.

"He was trying to change an image that had been planted over the past hundred years, of the agricultural sciences not being up to snuff to any other science," agrees Karl Glasener, head of science policy for the American Society of Agronomy, the Crop Science Society of America, and the Soil Science Society of America, all in Washington DC. "The only way we were going to get attention was to do big bold things that result in something we could sell to policy-makers."

But some researchers who were up for grant renewals last year found that the AFRI no longer had a programme that matched their research goals. Others worried that the focus on larger, more interdisciplinary projects worked against young researchers, who are unlikely to have established the reputation needed to head or be recruited to a large research team. "It was a dramatic shift which had some collateral damage," says Bertsch.

Beachy notes with pride that the 1,557 grant applications the AFRI received last year amounted to a total funding request of US $\$ 4$ billion, nearly four times the amount requested in 2009 and well beyond the initiative's \$262.5-million budget for 2010 (see 'A growing concern'). But Rebecca McCulley, an ecologist at the University of Kentucky, sees a high volume of requests as a sign of desperation in the face of so much uncertainty about what the AFRI will fund. "We've all been hammered," she says, "and people are trying to squeeze in an application wherever they can."

Beachy expected criticism. "We knew what we were doing last year, and we expected the response we got," he says. But he has taken steps to address the community's concerns. In the next round of funding, a larger share of the AFRI's budget will go to individual researchers. And the calls for grants so far this year have been less specific, he says, allowing researchers more flexibility to submit novel proposals.

Meanwhile, a changing climate in Washington DC has created new challenges for the programme. Committees in the US Congress originally approved a $20 \%$ boost in NIFA's grants budget for 2011. Instead, with Congress fixated on cutting deficits, funding has been held at roughly 2010 levels.

It is unclear who will step into Beachy's shoes. Catherine Woteki, chief scientist at the USDA, says that the agency will be searching for "another distinguished scientist". Until someone is found, Chavonda Jacobs-Young, director of the office of the chief scientist at the USDA, will serve as interim director. Whoever takes on the position will need to be tough enough fight off criticism, says Bertsch, if the AFRI redesign is to succeed.

Although the future of his revolution is cloudy, with its champion gone and its budget facing cuts in 2012 if legislators follow through on threats to trim spending further, Beachy doesn't plan to disappear entirely. "I'm not done advocating for agricultural research," he says. "It's just that I need to do it from St Louis.”

\section{CORRECTION}

The graph 'Stalled progress' in the News Feature 'The pull of stronger magnets' (Nature 472, 22-23; 2011) incorrectly labelled one line as samarium-iron-nickel. This should have read samarium-iron-nitrogen. 